\title{
Investigation of the Relationship Between Nurses' Burnout and Psychological Resilience Levels
}

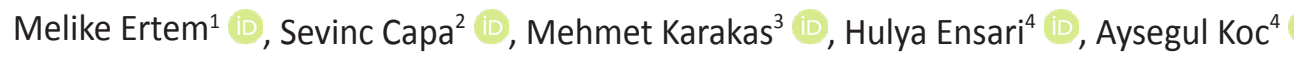 \\ ${ }^{1}$ Izmir Katip Celebi University Health Sciences Faculty, Department of Psychiatric Nursing, Izmir, Turkey \\ ${ }^{2}$ Bolu Izzet Baysal Psychiatric and Mental Health Hospital, Nursing Services, Bolu, Turkey \\ ${ }^{3}$ Bolu Abant Izzet Baysal University, Department of Psychiatric Nursing, Bolu, Turkey \\ ${ }^{4}$ Bolu Izzet Baysal Psychiatric and Mental Health Hospital, Bolu, Turkey \\ Correspondence Author: Melike Ertem \\ E-mail: melike_yonder@hotmail.com
}

Received: $02.08 .2019 \quad$ Accepted: 22.11 .2019

\begin{abstract}
Objective: This descriptive and correlational study was performed to determine the relationship between resilience and burnout levels of nurses working in psychiatry clinics.

Methods: The population of this correlational study comprised 70 nurses, 55 of which constituted the study sampling between February and May in 2018. Research data was collected by means of "Personal Information Form", "Psychological Resilience Scale/PRS" and "Maslach Burnout Scale/MBS".

Results: "Devotion" subscale of PRS showed a strong statistically significant inverse relationship with "Emotional Burnout" subscale of MBS $(r=-0.707 ; p=0.000)$ albeit a moderate statistically significant inverse relationship noted with both "Desensitization" and "Personal Success" subscales of MBS $(p<0.05)$.

Conclusion: The results of this study may help nurse managers and hospital administrators to have a better understanding of nurses' burnout and resilience levels. Future studies on the determination of compassion fatigue, which is an expression of empathy fatigue against nurses in psychiatric clinics and particularly Community Mental Health Services, are highly recommended.
\end{abstract}

Keywords: Burnout, Psychiatric Nursing, Resilience.

\section{INTRODUCTION}

Resilience is the ability of an individual to successfully overcome and adapt to adverse conditions. Although it is defined as a talent and a psychological quality, resilience has a number of features such as contribution to the maintenance of healthy development and coping capacity with a negative situation (1,2). Masten et.al. (1990), while defining the concept of resilience have touched on three basic features (1). The first basic resilience; people who live in negative conditions and who have high risk have a personal ability to survive in difficult conditions and to overcome difficulties. The second basic resilience; expresses the ability of the people with difficult and stressful life to adapt quickly with the experiences they have gained under these negative conditions. The third resilience; refers to psychological concussion at times like losing a loved one, accidents and natural disasters (1). The ability to cope with such difficult situations and get rid of the effects of trauma are considered within the third group.

Despite difficult working conditions, psychiatric and mental health nurses' ability to carry on their professional clinical skills, cope with challenging situations and retain their empathic and willing states are realized thru their resilience (2-4). Thus, resilience is reported to be a key factor in job satisfaction, depression and burnout in nurses and especially in nurses who work at psychiatric and mental health services (3-5).

Burnout experience leads to job dissatisfaction, prevention of professionalism, patient dissatisfaction, reduced nurse productivity, low quality of life and low quality of care (69). Meanwhile, studies assert that burnout contributes to the problem of nurse scarcity (10). The effect of burnout not only is limited to the nurses experiencing it but also filters thru their patients, institutions, affiliated society, family and friends (11).

According to the relevant literature, in the event of an encounter with an unforeseen stressful situation, nurses reported improved resilience by the adoption of protective factors (personal, social, professional) $(12,13)$. Furthermore, resilience welcomes the adoption of skills 
such as self-confidence, autonomy, coping, adaptation and creating motivational life force (14-19). Accordingly, positive amelioration is observed in personal and professional outcomes, job and life satisfaction, and development of professional nursing skills while staff turnover, sense of burnout and depression decrease $(14,15,20,21)$.

Nurses are the most risky group among the health care professionals in terms of stressors arising from the work environment. Nurses often experience work stress, are exposed to psychological violence in the workplace, and suffer from secondary traumatic stress and burnout. The problems experienced by the nurses negatively affect the physical, mental and social health of the nurses. Mental distress decreases the efficiency of nurses, as a result of which both patient quality of care and institutions are adversely affected. The concepts of coping skills, social support and resilience come into prominence in the protection and strengthening of mental health of nurses $(12,15,18)$. It is vital to determine the level of resilience especially in nursing and take preventive actions before burnout takes place. The literature review yielded no studies that focused on both the resilience and burnout concepts featuring psychiatric nurses/nurses work in psychiatric clinics. For these reasons, it is the aim of our study to determine the relationship between resilience and burnout levels of nurses working in psychiatry clinics.

The research questions:

What are the sociodemographic characteristics of nurses?

What are the sociodemographic characteristics that affect the resilience level of nurses works in psychiatric clinics?

What are the sociodemographic characteristics that affect the burnout level of nurses works in psychiatric clinics?

Is there any relationship between resilience and burnout levels of nurses works in psychiatric clinics?

\section{METHODS}

\section{Study design}

This research was designed as a descriptive and correlational study.

\section{Settings and participant}

This study was carried out in Bolu İzzet Baysal Mental Health and Diseases Training and Research Hospital. The data was collected between February and May in 2018. The population of this study comprised 70 nurses who work in a mental health and diseases education and research hospital. Sampling method was not used in the study, it is aimed to reach the whole population. Reasons about maternity leave, military service, annual leave the study sampling was carried out by selecting 55 nurses that accepted to participate in the study and filled out the data collection forms completely.

\section{Data Collection}

The research data collection was carried out by means of selfreport methods such as survey and scales, namely, "Personal Information Form", "Psychological Resilience Scale" and "Maslach Burnout Scale".

Personal information form: This form was developed by researchers. It solicits information such as age, work experience, education level, perception of job satisfaction level, monthly night shift frequency and staffing status, all of which relate to occupational burnout $(7,20)$

Psychological resilience scale (PRS): Psychological resilience scale was developed by Terzi (2016) to determine resilience level, consists of 21 items and three sub-dimensions indicating the beliefs of the individual about himself/herself and his/ her life (22). The psychological resilience scale is a 5-point Likert-type scale scored between $0-4$ and items of the scale are marked as (0) strongly disagree, (1) disagree, (2) neutral, (3) agree, (4) strongly agree. Psychological resilience scale includes direct expressions and reverse expressions, and items 2 and 15 are scored in reverse direction. Exploratory and confirmatory factor analyses were administrated in order to determine the construct validity of the scale, and it was found out that the scale consisted of 21 items and three subdimensions. These dimensions were called Self-Commitment (PRS-SC), Control (PRS-C) and Challenging (PRS-CH) in the light of literature. General resilience score is obtained after scoring three sub-dimensions separately. While high scores of scale indicate that resilience reduces, low scores refer that resilience increases.

Maslach burnout scale (MBS): MBS, developed by Maslach and Jackson in 1981 to determine the level of burnout of individuals, consists of 22 items and 3 subdimensions (emotional burnout, desensitization, personal success). MBS was set on a 5-point Likert scale, in the order of (0) never, (1) seldom, (2) sometimes, (3) frequently and (4) always. In detail, MBS is calculated by the sum of scores for 22 items spanned across 3 subdimensions, namely, emotional burnout (items $1,2,3,6,8,13,14,16,20$ ), desensitization (items 5, 10, 11, 15,22 ) and personal success (items 4, 7, 9, 12, 17, 18, 19, 21). Higher scores in "Emotional Burnout" and "Desensitization" subscales and a lower score in "Personal Success" subscale are clear indications of a high level of burnout. "Emotional Burnout" represents the individual stress dimension of burnout and imply a diminution of an individual's emotional and physical resources. "Desensitization" represents the inter-personal dimension of burnout that includes negative, rigid attitudes towards patients and unresponsiveness to work. On the other hand, low level of "Personal Success" refers to an individual's negative self-assessment tendency.

\section{Ethical Consideration}

Permission to conduct the study was granted by the Abant İzet Baysal University Human Research Ethics Committee (No: 2018/23), which serves as the institutional review board for clinical research. All participants completed the approved 
informed consent procedures and were assured that they had the right to refuse to participate in the study.

\section{Statistical Analysis}

Statistical data analyses were carried out using SPSS. Frequency tables and descriptive statistics were utilized to interpret the findings. Student t tests, the One way ANOVA test and Tukey HSD, Tamhane tests were used for comparison of the groups. For determining correlation between Pearson's and Spearman correlation was deployed. The correlation between levels PRS and MBS subscales were analyzed using Pearson's and Spearman correlation analysis. $p<0.05$ was considered statistically significant.

\section{RESULTS}

\section{The Socio-demographic Characteristics of Nurses}

The mean age of sample population was $36.47 \pm 7.76$ (years). $72.7 \%$ of the participants were women, $63.6 \%$ were married and $52.7 \%$ had bachelor's degree. $65.5 \%$ of the participants had 6 years or more work experience in the psychiatric clinic and $54.5 \%$ had a total of 16 years or more work experience (Table 1).

\section{Research Findings of PRS Sub-dimensions According to Sociodemographic Characteristics}

There was a statistically significant difference between PRS total scores and "Challenge" subscale scores with respect to nurse age $(t=2.647 ; p=0.011 ; t=2.128 ; p=0.038)$. "Challenge" subscale score and total scale score of 35 years old and younger nurses were statistically significantly higher than that of 36 years old or older nurses (Table 2).

"Control" subdimension scores of PRS with respect to gender showed a statistically significant difference ( $t=-2.246$; $\mathrm{p}=0.029$ ). As such, "Control" subdimension score of male nurses were statistically significantly higher (Table 2).

"Devotion" subscale scores versus total PRS scores with respect to the affiliated psychiatry department yielded statistically significant differences $(\chi 2=7.836 ; p=0.020$; $\chi 2=6.445 ; p=0.040)$.
Table 1. The Socio-demographic Characteristics of Nurses

\begin{tabular}{|c|c|c|}
\hline Variable $(\mathrm{N}=55)$ & $n$ & $\%$ \\
\hline $\begin{array}{l}\text { Age ( } \bar{x} \pm s s .36,47 \pm 7,76 \text { (years) } \\
35 \text { years-old and below } \\
36 \text { years-old and above }\end{array}$ & $\begin{array}{l}22 \\
33\end{array}$ & $\begin{array}{l}40.0 \\
60.0\end{array}$ \\
\hline $\begin{array}{l}\text { Gender } \\
\text { Female } \\
\text { Male }\end{array}$ & $\begin{array}{l}40 \\
15\end{array}$ & $\begin{array}{l}72.7 \\
27.3\end{array}$ \\
\hline $\begin{array}{l}\text { Marital Status } \\
\text { Married } \\
\text { Single }\end{array}$ & $\begin{array}{l}35 \\
20\end{array}$ & $\begin{array}{l}63.6 \\
36.4\end{array}$ \\
\hline $\begin{array}{l}\text { Number of Children } \\
1 \text { child } \\
2 \text { children and more }\end{array}$ & $\begin{array}{c}6 \\
29\end{array}$ & $\begin{array}{l}17.1 \\
82.9\end{array}$ \\
\hline $\begin{array}{l}\text { Education Level } \\
\text { Health Vocational High School } \\
\text { Bachelor's Degree } \\
\text { Graduate Degree } \\
\text { Post-Graduate Degree }\end{array}$ & $\begin{array}{c}8 \\
13 \\
29 \\
5\end{array}$ & $\begin{array}{r}14.6 \\
23.6 \\
52.7 \\
9.1\end{array}$ \\
\hline $\begin{array}{l}\text { Work Experience } \\
5 \text { years or less } \\
6-10 \text { years } \\
11-15 \text { years } \\
16 \text { years or more }\end{array}$ & $\begin{array}{c}10 \\
7 \\
8 \\
30\end{array}$ & $\begin{array}{l}18.3 \\
12.7 \\
14.5 \\
54.5\end{array}$ \\
\hline $\begin{array}{l}\text { Work Experience in Psychiatry } \\
5 \text { years and below } \\
6 \text { years and above }\end{array}$ & $\begin{array}{l}19 \\
36\end{array}$ & $\begin{array}{l}34.5 \\
65.5\end{array}$ \\
\hline $\begin{array}{l}\text { Department of Psychiatry } \\
\text { Services } \\
\text { Polyclinic } \\
\text { Community Mental Health Services (CMHS) }\end{array}$ & $\begin{array}{c}39 \\
9 \\
7\end{array}$ & $\begin{array}{l}70.9 \\
16.4 \\
12.7\end{array}$ \\
\hline $\begin{array}{l}\text { Night Shifting Status } \\
\text { Yes } \\
\text { No }\end{array}$ & $\begin{array}{l}45 \\
10\end{array}$ & $\begin{array}{l}81.8 \\
18.2\end{array}$ \\
\hline $\begin{array}{l}\text { Night Shift Frequency } \\
\text { Once a month } \\
2-3 \text { times a month } \\
4-5 \text { times a month } \\
6 \text { times and above a month }\end{array}$ & $\begin{array}{c}11 \\
5 \\
15 \\
14\end{array}$ & $\begin{array}{l}24.5 \\
11.1 \\
33.3 \\
31.1\end{array}$ \\
\hline $\begin{array}{l}\text { Staffing Status } \\
\text { On-Contract } \\
\text { Permanent }\end{array}$ & $\begin{array}{c}7 \\
48\end{array}$ & $\begin{array}{l}12.7 \\
87.3\end{array}$ \\
\hline $\begin{array}{l}\text { Job Satisfaction Level } \\
\text { Moderate } \\
\text { High }\end{array}$ & $\begin{array}{l}23 \\
32\end{array}$ & $\begin{array}{l}41.8 \\
58.2\end{array}$ \\
\hline
\end{tabular}


Table 2. Comparison of PRS and MBS with respect to Research Findings

\begin{tabular}{|c|c|c|c|c|c|c|c|c|c|}
\hline \multirow{2}{*}{\multicolumn{2}{|c|}{ Variable $(\mathrm{N}=55)$}} & \multirow{3}{*}{$\begin{array}{l}n \\
22 \\
33 \\
\end{array}$} & \multicolumn{4}{|c|}{ PRS } & \multicolumn{3}{|c|}{ MBS } \\
\hline & & & \multirow{2}{*}{\begin{tabular}{|r|} 
Devotion \\
$20,41 \pm 3,80$ \\
$19,85 \pm 3,27$ \\
\end{tabular}} & \multirow{2}{*}{$\begin{array}{c}\text { Control } \\
19,5[14,0-25,0] \\
17,0[13,0-21,0]\end{array}$} & \multirow{2}{*}{$\begin{array}{r}\text { Challenge } \\
22,95 \pm 2,80 \\
20,58 \pm 3,54\end{array}$} & \multirow{2}{*}{$\begin{array}{r}\text { TOTAL } \\
62,50 \pm 8,16 \\
58,00 \pm 7,35\end{array}$} & \multirow{2}{*}{$\begin{array}{c}\text { Emotional } \\
\text { Burnout } \\
12,14 \pm 5,46 \\
13,18 \pm 5,97\end{array}$} & \multirow{2}{*}{$\begin{array}{l}\text { Desensitization } \\
5,00 \pm 3,92 \\
4,72 \pm 3,58\end{array}$} & \multirow{2}{*}{$\begin{array}{r}\begin{array}{c}\text { Personal } \\
\text { Success }\end{array} \\
7,80 \pm 3,65 \\
10,76 \pm 4,32\end{array}$} \\
\hline Age & $\begin{array}{l}35 \text { years old and more } \\
36 \text { years old and less }\end{array}$ & & & & & & & & \\
\hline & $\begin{array}{l}\text { Statistical Analysis* } \\
\text { Possibility }\end{array}$ & & $\begin{array}{l}t=0,584 \\
p=0,562\end{array}$ & $\begin{array}{l}Z=-1,889 \\
p=0,059\end{array}$ & $\begin{array}{l}t=2,647 \\
p=0,011\end{array}$ & $\begin{array}{l}t=2,128 \\
p=0,038\end{array}$ & $\begin{array}{l}t=-0,658 \\
p=0,514\end{array}$ & $\begin{array}{l}t=0,267 \\
p=0,791\end{array}$ & $\begin{array}{l}t=-0,074 \\
p=0,941\end{array}$ \\
\hline \multirow[t]{2}{*}{ Gender } & $\begin{array}{l}\text { Female } \\
\text { Male }\end{array}$ & $\begin{array}{l}40 \\
15\end{array}$ & $\begin{array}{l}19,73 \pm 3,43 \\
21,00 \pm 3,51\end{array}$ & $\begin{array}{l}17,73 \pm 2,57 \\
19,47 \pm 2,53\end{array}$ & $\begin{array}{l}21,5[14,0-28,0] \\
21,0[8,0-27,0]\end{array}$ & $\begin{array}{l}59,15 \pm 7,78 \\
61,53 \pm 8,32\end{array}$ & $\begin{array}{l}12,95 \pm 5,95 \\
12,26 \pm 5,31\end{array}$ & $\begin{array}{l}4,53 \pm 3,49 \\
5,67 \pm 4,17\end{array}$ & $\begin{array}{l}11,28 \pm 4,39 \\
9,47 \pm 4,31\end{array}$ \\
\hline & $\begin{array}{l}\text { Statistical Analysis* } \\
\text { Possibility }\end{array}$ & & $\begin{array}{l}t=-1,220 \\
p=0,228\end{array}$ & $\begin{array}{l}t=-2,246 \\
p=0,029\end{array}$ & $\begin{array}{l}Z=-0,086 \\
p=0,932\end{array}$ & $\begin{array}{l}t=-0,993 \\
p=0,325\end{array}$ & $\begin{array}{l}t=0,390 \\
p=0,698\end{array}$ & $\begin{array}{l}t=-1,024 \\
p=0,311\end{array}$ & $\begin{array}{l}t=-1,368 \\
p=0,177\end{array}$ \\
\hline \multirow[t]{2}{*}{$\begin{array}{l}\text { Psychiatry } \\
\text { Department }\end{array}$} & $\begin{array}{l}\text { Services } \\
\text { (1) } \\
\text { Polyclinic }{ }^{(2)} \\
\text { CMHS }^{(3)}\end{array}$ & $\begin{array}{l}39 \\
9 \\
7\end{array}$ & $\begin{array}{l}20,0[14,0-26,0] \\
22,0[19,0-25,0] \\
17,0[15,0-20,0]\end{array}$ & $\begin{array}{l}18,0[13,0-25,0] \\
19,0[14,0-21,0] \\
16,0[13,0-21,0]\end{array}$ & $\begin{array}{l}22,0[8,0-28,0] \\
22,0[18,0-27,0] \\
20,0[16,0-27,0]\end{array}$ & $\begin{array}{l}60,0[42,0-78,0] \\
62,0[53,0-72,0] \\
50,0[49,0-68,0]\end{array}$ & $\begin{array}{l}12,95 \pm 5,40 \\
7,33 \pm 3,81 \\
18,71 \pm 2,63\end{array}$ & $\begin{array}{l}4,0[0,0-16,0] \\
2,0[0,0-8,0] \\
6,0[2,0-9,0]\end{array}$ & $\begin{array}{l}10,46 \pm 4,58 \\
9,33 \pm 3,87 \\
14,43 \pm 1,51\end{array}$ \\
\hline & $\begin{array}{l}\text { Statistical Analysis* } \\
\text { Possibility }\end{array}$ & & $\begin{array}{l}\chi^{2}=7,836 \\
p=0,020 \\
{[2-3]}\end{array}$ & $\begin{array}{l}\chi^{2}=4,315 \\
p=0,116\end{array}$ & $\begin{array}{l}\chi^{2}=3,445 \\
p=0,179\end{array}$ & $\begin{array}{l}\chi^{2}=6,445 \\
p=0,040 \\
{[2-3]}\end{array}$ & $\begin{array}{l}F=10,557 \\
p=0,000 \\
{[1-2,3][2-3]}\end{array}$ & $\begin{array}{l}\chi^{2}=4,634 \\
p=0,099\end{array}$ & $\begin{array}{l}F=2,925 \\
p=0,063\end{array}$ \\
\hline \multirow[t]{2}{*}{$\begin{array}{l}\text { Work } \\
\text { Experience }\end{array}$} & $\begin{array}{l}5 \text { years and more }{ }^{(1)} \\
6-10 \text { years }^{(2)} \\
11-15 \text { years }^{(3)} \\
16 \text { years and more }\end{array}$ & $\begin{array}{l}10 \\
7 \\
8 \\
30\end{array}$ & $\begin{array}{l}18,90 \pm 3,25 \\
22,57 \pm 3,46 \\
20,25 \pm 4,68 \\
19,83 \pm 3,05 \\
\end{array}$ & $\begin{array}{l}18,00 \pm 2,71 \\
19,29 \pm 3,45 \\
19,38 \pm 3,34 \\
17,70 \pm 2,18 \\
\end{array}$ & $\begin{array}{l}22,0[20,0-27,0] \\
23,0[19,0-27,0] \\
21,0[16,0-28,0] \\
21,0[8,0-27,0] \\
\end{array}$ & $\begin{array}{l}59,60 \pm 6,11 \\
65,14 \pm 9,44 \\
60,62 \pm 11,09 \\
58,40 \pm 6,94\end{array}$ & $\begin{array}{l}14,70 \pm 5,74 \\
7,42 \pm 4,54 \\
12,37 \pm 5,50 \\
13,47 \pm 5,56\end{array}$ & $\begin{array}{l}6,80 \pm 4,29 \\
2,00 \pm 1,53 \\
3,75 \pm 3,15 \\
5,13 \pm 3,61\end{array}$ & $\begin{array}{l}12,10 \pm 3,14 \\
9,00 \pm 6,63 \\
9,00 \pm 5,04 \\
11,23 \pm 3,91\end{array}$ \\
\hline & $\begin{array}{l}\text { Statistical Analysis* } \\
\text { Possibility }\end{array}$ & & $\begin{array}{l}F=1,712 \\
p=0,176\end{array}$ & $\begin{array}{l}F=1,308 \\
p=0,282\end{array}$ & $\begin{array}{l}\chi^{2}=3,799 \\
p=0,284\end{array}$ & $\begin{array}{l}F=1,436 \\
p=0,243\end{array}$ & $\begin{array}{l}F=2,810 \\
p=0,049 \\
{[1-2]}\end{array}$ & $\begin{array}{l}F=2,902 \\
p=0,044 \\
{[1-2]}\end{array}$ & $\begin{array}{l}F=1,241 \\
p=0,305\end{array}$ \\
\hline \multirow[t]{2}{*}{$\begin{array}{l}\text { Night Shift } \\
\text { Frequency }\end{array}$} & $\begin{array}{l}\text { Once a month } \\
2-3 \text { times a month } \\
4-5 \text { times a month } \\
6 \text { times and more }\end{array}$ & $\begin{array}{l}11 \\
5 \\
15 \\
14 \\
\end{array}$ & $\begin{array}{l}20,00 \pm 3,52 \\
16,80 \pm 2,59 \\
19,27 \pm 3,59 \\
21,28 \pm 3,03\end{array}$ & $\begin{array}{l}18,09 \pm 3,21 \\
16,20 \pm 2,59 \\
18,60 \pm 2,20 \\
18,93 \pm 2,70 \\
\end{array}$ & $\begin{array}{l}22,18 \pm 3,54 \\
18,60 \pm 2,88 \\
21,53 \pm 1,73 \\
21,29 \pm 4,91 \\
\end{array}$ & $\begin{array}{l}60,27 \pm 9,29 \\
51,60 \pm 4,83 \\
59,40 \pm 5,78 \\
61,50 \pm 8,79 \\
\end{array}$ & $\begin{array}{l}19,0[4,0-23,0] \\
18,0[8,0-23,0] \\
15,0[9,0-21,0] \\
10,0[0,0-18,0]\end{array}$ & $\begin{array}{l}5,64 \pm 4,13 \\
4,80 \pm 1,30 \\
6,13 \pm 3,94 \\
3,64 \pm 3,30 \\
\end{array}$ & $\begin{array}{l}13,0[1,0-16,0] \\
13,0[8,0-17,0] \\
11,0[3,0-19,0] \\
10,0[2,0-21,0]\end{array}$ \\
\hline & $\begin{array}{l}\text { Statistical Analysis* } \\
\text { Possibility }\end{array}$ & & $\begin{array}{l}F=2,445 \\
p=0,078\end{array}$ & $\begin{array}{l}F=1,375 \\
p=0,264\end{array}$ & $\begin{array}{l}F=1,220 \\
p=0,315\end{array}$ & $\begin{array}{l}F=2,108 \\
p=0,114\end{array}$ & $\begin{array}{l}\chi^{2}=8,911 \\
p=0,030 \\
{[1-4]}\end{array}$ & $\begin{array}{l}F=1,258 \\
p=0,302\end{array}$ & $\begin{array}{l}\chi^{2}=2,482 \\
p=0,479\end{array}$ \\
\hline \multirow{2}{*}{$\begin{array}{l}\text { Job } \\
\text { Satisfaction } \\
\text { Level }\end{array}$} & $\begin{array}{l}\text { Moderate } \\
\text { High }\end{array}$ & $\begin{array}{l}23 \\
32 \\
\end{array}$ & $\begin{array}{l}18,83 \pm 3,26 \\
20,97 \pm 3,38\end{array}$ & $\begin{array}{l}18,0[13,0-23,0] \\
18,0[14,0-25,0]\end{array}$ & $\begin{array}{l}21,0[8,0-28,0] \\
22,0[14,0-27,0]\end{array}$ & $\begin{array}{l}58,30 \pm 8,33 \\
60,88 \pm 7,58\end{array}$ & $\begin{array}{l}16,0[4,0-23,0] \\
11,0[0,0-23,0]\end{array}$ & $\begin{array}{l}6,04 \pm 3,43 \\
3,97 \pm 3,67\end{array}$ & $\begin{array}{l}11,0[2,0-17,0] \\
10,0[1,0-21,0]\end{array}$ \\
\hline & $\begin{array}{l}\text { Statistical Analysis* } \\
\text { Possibility }\end{array}$ & & $\begin{array}{l}t=-2,353 \\
p=0,022\end{array}$ & $\begin{array}{l}Z=-0,448 \\
p=0,654\end{array}$ & $\begin{array}{l}Z=-0,026 \\
p=0,646\end{array}$ & $\begin{array}{l}t=-1,191 \\
p=0,239\end{array}$ & $\begin{array}{l}Z=-2,936 \\
p=0,003\end{array}$ & $\begin{array}{l}t=2,125 \\
p=0,038\end{array}$ & $\begin{array}{l}Z=-1,602 \\
p=0,109\end{array}$ \\
\hline
\end{tabular}

PRS: resilience scale; MBS: Maslach burnout scale * a Kruskal-Wallis $H,{ }^{b}$ Indepedent Sample-t, c ANOVA, ${ }^{d}$ Mann-Whitney $U$

"Emotional Burnout" subscale of MBS with respect to the affiliated psychiatric clinic showed a statistically significant difference $(F=10.557 ; p=0.000)$.

Another statistically significant difference in MBS was determined between "Emotional Burnout" subscale scores of nurses with respect to monthly night shift frequency $(\chi 2=8.911 ; p=0.030)$.

A statistically significant difference in MBS was determined in terms of "Emotional Burnout" and "Desensitization" subscale scores with respect to nurses' perception of job satisfaction level $(Z=-2.936 ; p=0.003 ; t=2.125 ; p=0.038)$.

\section{The Correlation Between PRS and MBS Subscales}

"Devotion" subscale of PRS showed a strong statistically significant inverse relationship with "Emotional Burnout" subscale of MBS ( $r=-0.707 ; p=0.000$ ) albeit a moderate statistically significant inverse relationship noted with both "Desensitization" and "Personal Success" subscales of MBS $(p<0.05)$ (Table 3).
Table 3. The Correlation Between PRS and MBS Subscales

\begin{tabular}{|c|c|c|c|c|c|}
\hline \multirow{2}{*}{\multicolumn{2}{|c|}{$\begin{array}{l}\text { Correlation* } \\
(\mathrm{N}=55)\end{array}$}} & \multicolumn{4}{|c|}{ MBS } \\
\hline & & \multicolumn{2}{|c|}{$\begin{array}{c}\text { Emotional Bur- } \\
\text { nout }\end{array}$} & $\begin{array}{l}\text { Desensitiza- } \\
\text { tion }\end{array}$ & $\begin{array}{l}\text { Personal Suc- } \\
\text { cess }\end{array}$ \\
\hline \multirow{8}{*}{ PRS } & \multirow{2}{*}{ Devotion } & r & $-0,707$ & $-0,558$ & $-0,625$ \\
\hline & & $p$ & 0,000 & 0,000 & 0,000 \\
\hline & \multirow{2}{*}{ Control } & $r$ & $-0,287$ & $-0,228$ & $-0,416$ \\
\hline & & $p$ & 0,034 & 0,095 & 0,002 \\
\hline & \multirow{2}{*}{ Challenge } & $r$ & $-0,299$ & $-0,103$ & $-0,305$ \\
\hline & & $p$ & 0,027 & 0,456 & 0,023 \\
\hline & \multirow{2}{*}{ Total } & $r$ & $-0,542$ & $-0,351$ & $-0,567$ \\
\hline & & $p$ & 0,000 & 0,009 & 0,000 \\
\hline
\end{tabular}

PRS: resilience scale; MBS: Maslach burnout scale *Pearson and Spearman

\section{DISCUSSION}

Ability of nurses working in psychiatric and mental health services in utilizing professional clinical skills for patient care despite difficult working conditions is a matter of presenting coping skills in the event of a challenging situation and retaining eagerness and empathetic thinking all of which 
are explained by resilience (2-4). In addition, resilience is regarded as an important factor related to job satisfaction, burnout and depression in mental health nursing (3-5). One of the main objectives of this study was to determine the resilience levels of nurses working in psychiatric and mental health services. Nurses often experience stressful life events in their work environment that led them to indirect traumatization. In particular, indirect trauma is of great importance to mental health and psychiatric nurses working with patients that feel stigmatized by society, have trouble in expressing themselves or have a history of traumatic life.

The factors were scrutinized, namely, depression, burnout, self-esteem and resilient personality trait in relation to resilience level of nurses, and concluded that nurses with higher resilience reported lesser depression, emotional burnout and desensitization (4). It was examined that the burnout and resilience levels of nurses working in military hospitals and reported an inverse correlation in between (11). The research findings concur with the above-mentioned literature. In our study, both "Psychological resilience scale challenge" subscale and total PRS scores of nurses aged 35 and under were statistically significantly higher than that of nurses aged 36 and older $(t=2.647 ; p=0.011 ; t=2.128 ; p=0.038)$. In contrast to our research findings, researchers such as Tekin (2011) whom studied nurses serving in military hospitals and Güngörmüş et al. (2015) whom studied at nursing students found no relationship between age and resilience. Discrepancy between this study and the literature can be related to several factors that impede resilience such as prolonged close interactions with patients and their relatives, caring patients with chronic psychiatric diseases, experiencing empathy fatigue, and vice versa.

In this study, the subscale scores pertinent to MBS were determined as low level, respectively. Low burnout scores in our study may be associated with various factors such as research sampling which consisted only nurses from psychiatric clinics or stressor perception differences were present among the nurses as to what may cause burnout.

It is determined that the nurses with 5 years and below work experience compared to the nurses with 6-10 years of work experience had scored higher in "Emotional Burnout" and "Desensitization" subscales. Parallel to our finding, it was reported high burnout and desensitization levels in nurses with meager work experience in a different study (23).

In our study, nurses taking six or more night shifts per month had lower emotional burnout level than the nurses taking only one night shift per month. Taking night shifts is common in many professions, especially in health care services. These can lead to emotional burnout due to physical fatigue and thus feeling of separation from home and family. Surprisingly, this research showed statistically significant inverse relationship between night shift and emotional burnout. This discrepancy is most likely caused by the fact that interaction between nurse and patient relatives are more frequent in the daytime than it is during the shift hours, which builds up emotional burnout in the psychiatric nurses over time.
In this study, nurses with high job satisfaction perception had lower emotional burnout and desensitization than the nurses with moderate job satisfaction perception. In fact, with respect to "Devotion" subscale, nurses with high job satisfaction perception presented higher resilience compared to the nurses with moderate job satisfaction. Tekin (11) identified total working hours and job satisfaction as the occupational attributes of nursing affecting resilience. The working environment factor has direct impact on the peace and success of the people, which is in concurrence with the results of our study. In a different study with the participation of 454 nurses and disclosed an evidence of a positive relationship between intention to stay at work and nurses' job satisfaction, psychological strength and stress resilience (24). Conclusively, it is tought that nurses may feel emotionally worn-out, desensitized and led to a decrease in their personal success. Conversely, willful working and higher job satisfaction have positive impact on the level of resilience unlike burnout.

Nurses working in outpatient clinics had the lowest emotional burnout among others working in the services and community mental health services (CHMS). Additionally, nurses working in CHMS had the highest emotional burnout levels. As an ancillary explanation for this phenomenon, nurses in outpatient clinics, unlike the ones in services or CHMS, do not take the responsibility of patient and patient care but rather attend interviews with the company of a physician. In a study, aimed at investigating the underlying reasons of psychological stress in burnout from a nurse standpoint, problems in communication with doctors (57\%), patient relatives (52\%), nursing management $(49 \%)$ and lastly patients $(40 \%)$ were enumerated in a descending order of magnitude (25). Another study, having reported "lack of respect" as the leading source of stress in nursing, enumerated an array of subordinate factors such as complaints of patients and their families, attitudes of patients under the influence of alcohol and pace of work, accountable for increased emotional burnout among nursing staff (26). Working in the services and CHMS, unlike outpatient clinics, requires constant interaction with patients and their families. In particular, having had difficulty to cope with patients with acute or chronic psychiatric illnesses, those nurses are prone to higher emotional burnout in tandem with work experience. In addition, working in the services demands high-level professional skill, teamworking and 24-hour servicing competence. Hence, it becomes inevitable to experience various work environment stresses and emotional burnout build-up over time. The presence of a higher emotional burnout level within CHMS nurses due to care of chronic psychiatric patients, suggests a difference in stress perceptions between nurses in the services and CHMS. The CHMS nurses furnish continuous training and consultancy services to both patients and their relatives while seeking a wide range of multidisciplinary input such as from psychologists, doctors, social workers, public education trainers and vice versa. On the other hand, as endorsed under CHSM nursing job description, CHSM nurses are required 
to fulfill responsibilities related to primary and tertiary protection in addition to secondary care. Eventually, this situation may form a basis for emotional burnout of CHSM nurses. Moreover, contrary to the patient group receiving treatment in the services, CHSM patients have to establish long-term interaction with the nurses following their discharge. Thus, CHSM nurses, having identified themselves with the feelings of patients experiencing internalized stigma, unemployment, disease difficulties and vice versa, will eventually suffer from empathy fatigue and emotional burnout. In fact, the evaluation of CHSM nurses for resilience yielded a lower resilience level with respect to dedication.

The total PRS scores are negatively associated with the total MBS scores and MBS subscale scores. Each individual perceives the stressor at different levels. These differences in perception of occupational stress are inversely related to burnout.

Burnout levels of nurses who exposed to more occupational stress were also found to be higher (27). Difficulty of caring patients suffering from a trauma or a natural disaster and being exposed to several patient sysmptoms during psychiatric patient care in mental health nursing such as patient stigmatization, isolation, guilt and disease, and incidents of violence, often lead to burnout, job dissatisfaction and depression amongst nurses $(3,5,12)$.

\section{CONCLUSION}

Resilience of nurses in psychiatry clinics vary by factors such as age, gender, job satisfaction and affiliated department, whereas burnout vary by factors such as affiliated department, work experience, night shift frequency and job satisfaction. The findings of this study can enrich our knowledge of the role of resilience in influencing nurse burnout at a correlational context. The results of this study show us the resilience of nurses vary by factors such as age, gender, affiliated department and perception of jobsatisfaction level, whilst their burnout rate vary by factors such as affiliated department, work hours, night shift frequency and job-satisfaction level

Nurse leaders as well as policymakers should take the initiative to launch courses, seminars, conferences, panels, workshops and structured training programs aimed at improving personal skills in the workplaces.

Although the significance of resilience is clear, a better understanding is needed of which factors affect a nurse's level of resilience and burnout and how resilience can best be improved and burnout level can be decreased. For this to happen, a more explicit definition of which resilience at nurses involves should be formulated and applied in a consistent manner. This will allow better theoretical models to be developed and evaluated.

All data were obtained from only in work in nurses one hospital. All data were based on the personal declaration of the nurses.
Acknowlegment: This study was presented as an oral presentation at V. International IX. National Psychiatric Nursing Congress, 2018, Antalya-TURKEY. (20-23 October 2018)

\section{REFERENCES}

[1] Masten AS, Coatsworth JD. The development of competence in favorable and unfavorable environments: Lessons from research on successful children. Am Psychol 1998; 53(2): 205230.

[2] Öz F, Bahadır-Yılmaz E. A significant concept in protecting mental health: Resilience. H.U. Fac of Health Sci J 2009; 16(3): 82-89.

[3] Matos PS, Neushotz LA, Griffin MTQ, Fitzpatrick JJ. An exploratory study of resilience and job satisfaction among psychiatric nurses working in inpatient units. Int J Ment Health Nurs 2010; 19(5): 307-312.

[4] Gito $M$, Ihara $H$, Ogata $H$. The relationship of resilience, hardiness, depression and burnout among Japanese psychiatric hospital nurses. J Nurs Educ Pract 2013; 3(11): 1218.

[5] Warelow P, Edward KL. Caring as a resilient practice in mental health nursing. Int J Ment Health Nurs 2007; 16(2): 132-135.

[6] Duquette A, Kerouac S, Sandhu B, Beaudet L. Factors related to nursing burnout: a review of empirical knowledge. Issues Ment Health Nurs 1994; 15(4): 337-358.

[7] Ergin D, Celasin N, Akış Ş, Altan Ö, Bakırlıoğlu Ö, Bozkurt S. Burnout and empathic skill levels and influencing factors of Internal medicine nurses. Firat Health Serv J 2009; 4(11): 4964 (In Turkish).

[8] Lee H, Song R, Cho YS, Lee GZ, Daly B. A comprehensive model for predicting burnout in Korean nurses. J of Adv Nurs 2003; 44(5): 534-545.

[9] Vahey DC, Aiken LH, Sloane DM, Clarke S, Vargas D. Nurse burnout and patient satisfaction. Med Care 2004; 42(2): 11571166.

[10] Alimoglu MK, Donmez L. Daylight exposure and the other predictors of burnout among nurses in a University Hospital. Int J of Nurs Studies 2005; 42(5): 549-555.

[11] Tekin E. Determination of Psychological Endurance and Burnout Levels of Nurses Working in Military Hospitals. Gazi University Institute of Health Sciences, Master Thesis. 2011.

[12] McAllister M, Lowe JB. The Resilient Nurse: Empowering Your Practice. Eds. New York: Springer Publishing Company, 2011.

[13] Cusack L, Smith M, Hegney D, Rees CS, Breen LJ, Witt RR, Rogers C, Williams A, Cross W, Cheung K. Exploring Environmental Factors in Nursing Workplaces That Promote Psychological Resilience: Constructing a Unified Theoretical Model. Front Psychol 2016; 7: 600.

[14] McAllister M, McKinnon J. The importance of teaching and learning resilience in the health disciplines: a critical review of the literature. Nurs Edu T. 2009; 29(4): 371-379.

[15] McCann CM, Beddoe E, McCormick K, Huggard P, Kedge S, Adamson $C$, Huggard J. Resilience in the health professions: A review of recent literature. Int J of Wellbeing 2013; 3(1): 6081.

[16] McAllister M. Resilience: a personal attribute, social process and key Professional resource for the enhancement of the nursing role. Prof Inferm. 2013; 66: 55-62. 
[17] Editorial G. Coping with the professional identity crisis: Is building resilience the answer? Int J of Nurs Studies 2008; 45: 975-978.

[18] Gillespie BM, Chaboyer W, Wallis M, Grimbeek P. Resilience in the operating room: developing and testing of a resilience model. J Adv Nurs 2007; 59: 427-438.

[19] Pidgeon AM, Ford L, Klaassen F. Evaluating the effectiveness of enhancing resilience in human service professionals using a retreat-based Mindfulness with Metta Training Program: a randomised control trial. Psychol Health Med 2014; 19: 35564.

[20] Zander M, Hutton A, King L. Coping and resilience factors in pediatric oncology nurses. J Pediatr Oncol Nurs 2010; 27: 94108.

[21] JuSJ, Oh D. Relationships between nurses' resilience, emotional labor, turnover intention, job involvement, organizational commitment and burnout. Ind J of Sci and Tech 2016; 9: 1-5.
[22] Terzi Ş. Developing the psychological hardiness scale: the validity and reliability study. The J of Happy \& Well-Being 2016; 4(2): 165-182.

[23] Çınar S. Burnout in Nurses Working in State Hospital (Case of Karsiyaka State Hospital). Beykent University. Institute of Social Sciences, Master thesis. 2016 (In Turkish)

[24] Larrabee JH, Wu Y, Persily CA, Simoni PS, Johnston PA, Marcischak TL, Mott CL, Gladden SD. Influence of stress resiliency on RN job satisfaction and intent to stay. West J Nurs Res. 2010; 32: 81-102.

[25] Vimantaite R, Seskevicius A. The burnout syndrome among nurses working in lithuanian cardiac surgery centers. Medicina (Kaunas). 2006; 42(7): 600-605.

[26] Lewandowska A, Litwin B. Burnout as an occupational risk fornurses. Ann Acad Med Stetin. 2009; 55(3): 86-89.

[27] Mccraine EW, Lambert VA, Lambert CE. Work stres, hardiness and burnout among hospital staff nurses. Nursing Research. 1987; 36: 374-378. 